\title{
Ferritin and Serum Iron Levels among the ABO Blood Groups in Enugu, South Eastern Nigeria
}

Ifeanyichukwu Martin Ositadinma ${ }^{1 *}$, Amilo Grace Ifeoma ${ }^{1}$, Ngwu Amauche Martina $^{2}$, Obi Godwin Okorie ${ }^{2}$ and Okoye Augustine Ejike ${ }^{3}$

${ }^{1}$ Medical Laboratory Science, Nnamdi Azikiwe University, Nnewi Campus, Anambra state, Nigeria

${ }^{2}$ Department of Hematology and Immunology, Enugu State University of Science and Technology, Enugu, Enugu State, Nigeria

${ }^{3}$ Department of Hematology, Federal Teaching Hospital, Abakiliki, Ebonyi State, Nigeria

\begin{abstract}
Background: Iron deficiency anaemia is a common tropical disease. The understanding of the different blood groups ability to retain iron in their system can give an insight into their ability to handle the disease iron deficiency anaemia.

Objectives: The present study was designed to compare the level of ferritin, serum iron, total iron binding capacity (TIBC) and percentage transferrin saturation among the ABO blood groups in Enugu.

Methods: The study was prospectively conducted in 237 apparently healthy Nigerian volunteers in Enugu. Data were evaluated with SPSS (version 17) software and comparisons between groups were made using paired t-test.

Result: The results obtained showed that subjects with blood group B had lower values for ferritin (ng/mL) $(83.58 \pm 57.74)$ compared with Group A and O with ferritin $(\mathrm{ng} / \mathrm{mL})$ values of $158.80 \pm 24.87$ and $116.75 \pm 46.34$ respectively. Serum iron ( $\mu \mathrm{mol} / \mathrm{L})$ was also lowest in the group $B(20.20 \pm 8.07)$ compared with group $A$ and $O$ with serum iron $(\mu \mathrm{mol} / \mathrm{L})$ values of $34.40 \pm 15.44$ and $24.00 \pm 6.75$ respectively. No significant differences were observed in TIBC and percentage transferrin saturation among the different blood groups.
\end{abstract}

Conclusion: Blood group B subjects showed the lowest level of serum ferritin in this work.

Keywords: Ferritin; Serum iron; Total iron binding capacity; Transferrin saturation; $\mathrm{ABO}$

\section{Introduction}

Iron is a chemical element with the symbol Fe (from Latin: ferrum) and atomic number 26. It is a metal in the first transition series. Iron is a very important requirement for the formation of RBC. It forms a major portion of $\mathrm{Hb}$ molecule, the oxygen carrying pigment in the blood. It is required for $\mathrm{Hb}$ synthesis. Iron liberated from old $\mathrm{RBC}$ is normally retained and re-utilized [1]. The liver's stores of ferritin are the primary physiologic source of reserve iron in the body. The reserves of iron in adults in developing countries tend to be lower in children and women of child-bearing age, than in men and in the elderly $[2,3]$. Iron deficiency first attacks the storage iron in the body, and depletion of these stores is thought to be relatively non-symptomatic, although some vague and non-specific symptoms have been associated with it. Since so much iron is required for hemoglobin, iron deficiency anemia is the primary clinical manifestation of iron deficiency [4]. Serum contains a small amount of iron 14-32 $\mu \mathrm{mol} / \mathrm{L}$ (males) and $10-28 \mu \mathrm{mol} / \mathrm{L}$ (females) which is bound to the globulin fraction of serum proteins. The physical role of this protein bound iron is the transportation of iron in the body. Low values of serum iron are found in haemorrhagic and hypochromic types of anaemia, while high values are found in pernicious anaemia [5,6]. Presence of iron in the body is estimated by the determination of serum iron and Total Iron Binding Capacity (TIBC) of blood, which is the serum iron level when the iron transport protein transferrin is completely saturated [7].

The knowledge of blood grouping has helped tremendously in alleviating the complications hitherto associated with transfusion reactions. Interest in blood group research dates back to 1656, when Christopher Wren injected fluids into the veins of dogs [8]. The ABO blood group was discovered in 1900 - 1901 by Karl Landsteiner [9]. Blood group distribution in Nigerians (1gbo's, Hausa's and Yoruba's) have been documented and compared with those of the British [10]. There have been many documented evidence associating human blood groups with diseases. They include the protective effect of blood group $\mathrm{O}$ in rheumatic fever and its increased predisposition to duodenal ulcers, increased occurrence in group A of pernicious anaemia and Plasmodium Vivax malaria [11]. The present study was aimed at determining the levels of ferritin, Serum iron and TIBC in different $\mathrm{ABO}$ blood group systems in our environment, with a view of inferring from the result the possibility of any tendency to iron deficiency in any of the blood groups in the study area (Enugu state).

\section{Materials and Methods}

\section{Subjects}

A total of two hundred and thirty seven (237) apparently healthy volunteers were used for the study. The study was carried out in the Enugu State University Teaching Hospital, (ESUTH), a tertiary health facility situated in the Enugu Metropolis. ESUTH serves as a referral center for the primary and secondary health facilities in Enugu State and environs. Enugu State is in the South-East geographical zone of

*Corresponding author: Martin Ositadinma Ifeanyichukwu, Medica Laboratory Science, Nnamdi Azikiwe University, Nnewi Campus, Anambra state, Nigeria, Tel: 234 08037200407; Fax: 951032051; E-mail: moifeanyi@yahoo.co.uk

Received March 04, 2014; Accepted March 22, 2014; Published March 29 , 2014

Citation: Ositadinma IM, Ifeoma AG, Martina NA, Okorie OG, Ejike OA (2014) Ferritin and Serum Iron Levels among the ABO Blood Groups in Enugu, South Eastern Nigeria. J Blood Disorders Transf 5: 204. doi: 10.4172/2155-9864.1000204

Copyright: ( 2014 Ositadinma IM, et al. This is an open-access article distributed under the terms of the Creative Commons Attribution License, which permits unrestricted use, distribution, and reproduction in any medium, provided the original author and source are credited. 
Citation: Ositadinma IM, Ifeoma AG, Martina NA, Okorie OG, Ejike OA (2014) Ferritin and Serum Iron Levels among the ABO Blood Groups in Enugu, South Eastern Nigeria. J Blood Disorders Transf 5: 204. doi: 10.4172/2155-9864.1000204

Page 2 of 3

Nigeria. The subjects were all Nigerians irrespective of tribe. They were aged between 18 and 40years. The study was carried out from April to October 2012. Males were 189 while the females were 48. All subjects were screened using a HemoCue (Hb 301). Only subjects with hemoglobin levels of $>12.0 \mathrm{~g} / \mathrm{dL}$ for female and $>13.0 \mathrm{~g} / \mathrm{dL}$ for male were eligible for the study. ABO blood groups, ferritin, serum iron, TIBC and percentage transferrin saturation of the subjects were determined.

\section{Sample collection}

Under aseptic condition, $7 \mathrm{mls}$ of venous blood was collected from each subject by venepuncture using disposable pyrogen free needles and syringes. The left antecubital vein was used. The collected blood was put into a well labeled acid-washed plastic test tube, allowed to clot, centrifuged at a speed of 5,000 rotations per minute for 10 mins. The serum obtained was dispensed into another acid-washed test tube. The serum and the RBCs were stored at $4^{\circ} \mathrm{C}$ until ready for analysis.

\section{Methods}

Serum iron and total iron binding capacity (TIBC) were estimated using a ferrozine-based iron/TIBC reagent set (TECO DIAGNOSTICS, USA). Test procedure is based on the iron in serum being dissociated from its $\mathrm{Fe}$ (III)-transferrin complex by the addition of an acidic buffer containing hydroxylamine. This addition reduces the $\mathrm{Fe}$ (III) to $\mathrm{Fe}$ (II). The chromogenic agent, Ferene, form a highly colored Fe (II) complex that measured photometrically at $560 \mathrm{~nm}$.

The unsaturated iron binding capacity (UIBC) is determined by adding $\mathrm{Fe}$ (II) iron to serum so that they bind to the unsaturated iron binding sites on transferrin. The excess Fe (II) ions are reacted with Ferrozine to form the color complex, which measured photometrically. The difference between the amount of Fe (II) added and the amount of $\mathrm{Fe}$ (II) measured represents the unsaturated iron binding. The TIBC is determined by adding the serum iron value to the UIBC value.

Transferrin saturation percentage was calculated from the serum iron concentration and TIBC values as follows: transferrin saturation $=$ serum iron/TIBC $\mathrm{x}$ 100. Serum ferritin was measured using a human ferritin enzyme immunoassay kit (BIOCHECK, INC). The ferritin quantitative test is based on a solid phase enzyme-linked immunosorbent assay (ELISA). The assay was carried out on an ELISA machine (STAT FAX 2100, Awareness Technology, and USA). The assay system utilizes one rabbit anti- ferritin antibody for solid phase (microtiter wells) immobilization and mouse monoclonal antiferritin antibody in the antibody enzyme (horseradish peroxidase) conjugate solution. The test sample is allowed to react simultaneously with antibodies, resulting in the ferritin molecules being sandwiched between the solid phase and enzyme linked antibodies. After 45 minute incubation at room temperature, the wells are washed with water to remove unbounded labeled antibodies. A solution of TMB reagent is added and incubated at room temperature for 20 minutes, resulting in the development of a blue color. The color development is stopped with the addition of stop solution, and the color is changed to yellow and measured spectrophotometrically at $450 \mathrm{~nm}$. The concentration of ferritin is directly proportional to color intensity of the test sample.

Hemoglobin concentration was determined photometrically using the HemoCue meter ( $\mathrm{Hb} 301)$. The ABO blood groups were determined using the standard method described by Monica cheesbrough [12].

\section{Statistics}

Statistical analyses were conducted using SPSS (version 17) software. Ferritin, serum iron, total iron binding capacity and percentage transferrin saturation data's between the $\mathrm{ABO}$ blood groups were expressed as mean $+\mathrm{SD}$ and were compared using paired t-test. An alpha value of $<0.05$ denoted a statistically significant difference.

\section{Results}

A total of two hundred and thirty seven (237) apparently healthy volunteers were used for the study. The blood grouping result showed that only seven subjects (3.0\%) were blood group A, $52(21.9 \%)$ are blood group $\mathrm{B}$ and 178 (75.1\%) are blood group O. None of the subject is blood group $\mathrm{AB}(0 \%)$.

Table 1 shows the between group comparison of ferritin, serum iron, TIBC and percentage transferrin saturation (\%) between blood group $\mathrm{A}$ and $\mathrm{B}$. The results showed that ferritin and serum iron were significantly lower in blood group B than group A.

The result of Table 2 showed the between group comparisons of ferritin, serum iron, TIBC and percentage transferrin saturation of blood group A and O. Ferritin was significantly lower in blood group O when compared to blood group A. Others did not show significant difference in mean values.

When ferritin, serum iron, TIBC and percentage transferrin saturation of blood group B were compared with blood group $\mathrm{O}$, no significant difference was found in all the parameters (Table 3 ).

\section{Discussion}

Iron is an essential element required for many biochemical processes in the body. It plays a role in internal respiration and haemoglobin synthesis. The different cellular antigenic composition of $\mathrm{A}$ and $\mathrm{B}$ blood antigens can be suggested to enhance or inhibit the ability of the different $\mathrm{ABO}$ blood groups to perform varying biochemical roles [13].

\begin{tabular}{|c|c|c|c|}
\hline Parameters & Blood group A $(\mathbf{n}=\mathbf{7})$ & Blood group B $(\mathbf{n}=52)$ & P value \\
\hline Ferritin $(\mathrm{ng} / \mathrm{mL})$ & $158.80 \pm 24.87$ & $83.58 \pm 57.74$ & $0.00^{*}$ \\
Serum iron $(\mu \mathrm{mol} / \mathrm{L})$ & $34.40 \pm 15.44$ & $20.20 \pm 8.07$ & $0.02^{*}$ \\
TIBC $(\mu \mathrm{mol} / \mathrm{L})$ & $90.40 \pm 24.62$ & $72.70 \pm 16.06$ & 0.07 \\
Transferrin & $36.20 \pm 9.27$ & $27.00 \pm 17.44$ & 0.16 \\
Saturation $(\%)$ & & & \\
\hline
\end{tabular}

*Statistically significant $(p<0.05)$

Table 1: The between group comparisons of ferritin, serum iron, Total Iron Binding Capacity (TIBC) and percentage transferrin saturation in blood group $A$ and $B$.

\begin{tabular}{|c|c|c|c|}
\hline Parameters & Blood group A $(\mathbf{n}=7)$ & Blood group O $(\mathbf{n}=178)$ & P value \\
\hline Ferritin $(\mathrm{ng} / \mathrm{mL})$ & $158.80 \pm 24.87$ & $116.75 \pm 46.34$ & $0.02^{*}$ \\
Serum iron $(\mu \mathrm{mol} / \mathrm{L})$ & $34.40 \pm 15.44$ & $24.00 \pm 6.75$ & 0.07 \\
TIBC $(\mu \mathrm{mol} / \mathrm{L})$ & $90.40 \pm 24.62$ & $80.80 \pm 11.36$ & 0.28 \\
Transferrin & $36.20 \pm 9.27$ & $29.70 \pm 7.04$ & 0.94 \\
Saturation $(\%)$ & & & \\
\hline
\end{tabular}

Table 2: The between group comparison of ferritin, serum iron, TIBC and percentage transferrin saturation in blood group $\mathrm{A}$ and $\mathrm{O}$.

\begin{tabular}{|c|c|c|c|}
\hline parameters & Blood group B $(\mathbf{n = 5 2})$ & Blood group O $(\mathbf{n = 1 7 8})$ & P value \\
\hline Ferritin $(\mathrm{ng} / \mathrm{mL})$ & $83.58 \pm 57.74$ & $116.75 \pm 46.34$ & 0.15 \\
Serum iron $(\mu \mathrm{mol} / \mathrm{L})$ & $20.20 \pm 8.07$ & $24.00 \pm 6.75$ & 0.11 \\
TIBC $(\mu \mathrm{mol} / \mathrm{L})$ & $72.70 \pm 16.06$ & $80.80 \pm 11.36$ & 0.40 \\
Transferrin & $27.00 \pm 17.44$ & $29.70 \pm 7.04$ & 0.11 \\
Saturation $(\%)$ & & & \\
\hline
\end{tabular}

Table 3: The between group comparison of ferritin, serum iron, TIBC and percentage transferrin saturation in blood group $B$ and $O$. 
Citation: Ositadinma IM, Ifeoma AG, Martina NA, Okorie OG, Ejike OA (2014) Ferritin and Serum Iron Levels among the ABO Blood Groups in Enugu, South Eastern Nigeria. J Blood Disorders Transf 5: 204. doi: 10.4172/2155-9864.1000204

Page 3 of 3

Iron deficiency anaemia is characterized by low ferritin and Serum iron, raised TIBC and reduced percentage saturation of transferrin [14-18].

The results obtained showed that the mean ferritin, serum iron and TIBC are lowest in group B and highest in group A. However when compared with standard in the books $[8,19]$, they were within the normal range. The statistical differences in ferritin and Serum iron levels obtained between groups $\mathrm{A}$ and $\mathrm{B}$, also in ferritin between group $\mathrm{A}$ and $\mathrm{O}$ individuals may be as a result of the higher ferritin and Serum iron obtained in group A. The percentage saturation of transferrin is relatively constant in the different blood groups studied and lies within the normal range of $25 \%$ and $45 \%$. (Normally $1 / 3$ saturated by iron). There is paucity of information regarding ferritin, Serum iron, TIBC and percentage transferrin saturation (\% T.S) in the various ABO blood groups, but various studies have associated relationships between them and diseases like peptic ulcer in group $\mathrm{O}$ and bronchopneumonia in group A. Some authors have associated increase Serum iron and TIBC with predisposition to infections, the free iron being available for bacterial growth $[11,20]$. Our results on the percentage distribution of different blood groups agree with those already documented in the Lagos population [10].

\section{Conclusion}

The result of this research work concluded that the level of serum ferritin and serum iron were slightly lower in blood group B.

\section{Acknowledgement}

The authors wish to acknowledge all the volunteers. We are also grateful to the laboratory staff in the Department of Hematology in the Faculty of Medicine in Enugu State University of Science and Technology (ESUT) in Enugu, Nigeria.

\section{References}

1. Fleming RE, Bacon BR (2005) Orchestration of iron homeostasis. N Engl J Med 352: $1741-1744$.

2. De Domenico I, Ward DM, Kaplan J (2009) Specific iron chelators determine the route of ferritin degradation. Blood 114: 4546-4551.

3. Alvarez-Ossorio L, Kirchner H, Klüter H, Schlenke P (2000) Low ferritin levels indicate the need for iron supplementation: strategy to minimize iron-depletion in regular blood donors. Transfus Med 10: 107-112.

4. Javadzadeh Shahshahani H, Attar M, Taher Yavari M (2005) A study of the prevalence of iron deficiency and its related factors in blood donors of Yazd Iran, 2003. Transfus Med 15: 287-293.

5. Jeremiah ZA, Koate BB (2009) Reference percentiles of hematological and biochemical iron values of blood donors in Port Harcourt, Nigeria. Hematology 14: 366-370.

6. Mittal R, Marwaha N, Basu S, Mohan H, Ravi Kumar A (2006) Evaluation of iron stores in blood donors by serum ferritin. Indian J Med Res 124: 641-646.

7. Cançado RD, Chiattone CS, Alonso FF, Langhi Júnior DM, Alves Rde C (2001) Iron deficiency in blood donors. Sao Paulo Med J 119: 132-134.

8. Reid ME, Lomas-Francis C (2004) The Blood Group Antigen Facts Book (2ndedn), Elsevier Academic Press, New York.

9. Jeon H, Calhoun B, Pothiawala M, Herschel M, Baron BW (2000) Significant $A B O$ hemolytic disease of the newborn in a group $B$ infant with a group $A 2$ mother. Immunohematology 16: 105-108.

10. Iyiola OA, Igunnugbemi OO, Bello OG (2012) Gene frequencies of $A B O$ and $\mathrm{Rh}(\mathrm{D})$ blood group alleles in Lagos, South West Nigeria. Egyptian Journal of Medical Human Genetics 13: 147-153.

11. O'Donnell J, Laffan MA (2001) The relationship between ABO histo-blood group, factor VIII and von Willebrand factor. Transfus Med 11: 343-351.

12. Cheesbrough $M(2000)$ District laboratory practice in tropical countries, part-2, Cambridge University press, Cambridge, United Kingdom.

13. Yamamoto F, Clausen H, White T, Marken J, Hakomori S (1990) Molecular genetic basis of the histo-blood group ABO system. Nature 345: 229-233.

14. Boulton F (2008) Evidence-based criteria for the care and selection of blood donors, with some comments on the relationship to blood supply, and emphasis on the management of donation-induced iron depletion. Transfus Med 18: 13-27.

15. Farrugia $A$ (2007) Iron and blood donation- an under-recognised safety issue Dev Biol (Basel) 127: 137-146.

16. Nadarajan VS, Eow GI (2002) Anaemia and iron status among blood donors in a blood transfusion unit in Malaysia. Malays J Pathol 24: 99-102.

17. Bodnar LM, Cogswell ME, Scanlon KS (2002) Low income postpartum women are at risk of iron deficiency. J Nutr 132: 2298-2302.

18. Zimmermann MB, Hurrell RF (2007) Nutritional iron deficiency. Lancet 370 511-520.

19. Jandl JH (1996) Iron deficiency. In: Textbook of Haematology. (2ndedn), Little Brown and Company, London.

20. Simon TL (2002) Iron, iron everywhere but not enough to donate. Transfusion 42: 664 . 